\title{
First Amendment COMMERCial SPEECH Claims in Dentistry: How The Dental Profession's SPECIALTy Advertising Restrictions HaVe CoMe BaCK TO BITE THE ADA AND STATE Dental BoARdS
}

\author{
JAKE TORKEO* \\ INTRODUCTION
}

Advertising is an inescapable and increasingly prevalent aspect of life. Humans are incessantly presented with advertisements throughout the day from the moment they check their emails or open Twitter in the morning. A report published by Forbes in 2017 estimated that Americans are exposed to between 4,000 and 10,000 advertisements a day. ${ }^{1}$ But the noise and distractions caused by these ploys for our attention serve a purpose. Whether touting the latest and greatest nutritional fad, a streaming service full of binge-worthy series, or an investment platform capable of bringing you financial peace of mind, advertisements are produced with the same goals in mind: providing the consumer with information regarding the product or service, attracting the clientele that the producer of the advertisement seeks to engage, and increasing competition in the respective market.

The same principles apply to advertisements in the professional industries. Professionals in the legal and medical fields seek to inform prospective clients or patients about the specifics of the individual's practice and gain a competitive advantage over their peers. Often advertising is the most effective approach. Consumers of professional services, such as a client searching for an attorney to represent them or a patient seeking the expertise of a physician, are best served by receiving a wide array of information regarding the professionals available in their area. The more informed the consumer, the more likely they find the practitioner best suited to meet their needs.

However, professional associations such as the American Bar Association ("ABA"), American Medical Association ("AMA"), and the American Dental Association ("ADA") historically limited their members" ability to advertise under the guise of maintaining professional standards and protecting the easily influenced general public. ${ }^{2}$

* J.D. Candidate, 2020, Indiana University Robert H. McKinney School of Law; B.S., 2017, Indiana University - Purdue University Fort Wayne - Fort Wayne, Indiana.

1. Jon Simpson, Finding Brand Success in the Digital World, Forbes (Aug. 25, 2017), https:/www.forbes.com/sites/forbesagencycouncil/2017/08/25/finding-brand-success-in-the-digitalworld/\#39723c0d626e [https://perma.cc/ABQ9-8SCH].

2. Josh King, The Awful, No Good, Rule 7.2, Socially Awkward (Jan. 15, 2018), http://sociallyawkwardlaw.com/the-awful-no-good-rule-7-2/ [https://perma.cc/U7UN-AVR5]; see also Scott McDonald, A Helpful History of Practice Marketing, and What the Future Holds, DENTAL ECONOMics (July 14, 2017), https:/www.dentaleconomics.com/macro-op-ed/article/ $16389594 /$ a-helpful-history-of-practice-marketing-and-what-the-future-holds [https://perma.cc/6MJ7-CM75]. 
Today, the legal profession no longer follows that model. ${ }^{3}$ In 1977, the Supreme Court held that attorneys possess a right to free speech that trumps the ABA's interests in barring legal advertisements. ${ }^{4}$ In the subsequent decades, legal advertisements have become incredibly creative, albeit at times less than professional, with some attorneys and law firms going to extreme lengths to market their practices. In 2014, a Georgia law firm specializing in DUI defense distributed paper bags designed to conceal a beer can. ${ }^{5}$ In an effort to target their desired audience, the law firm's name on the bags was clearly designed to imitate a popular craft brewery's logo. ${ }^{6}$ In Texas, two attorneys wrote and performed a three-and-a-half-minute song entitled "Don't Eat Your Weed" in which the attorneys instructed prospective clients to avoid concealing or destroying marijuana during traffic stops to avoid felony charges. ${ }^{7}$ The song was played on local radio stations and posted on the law firm's YouTube channel where it has received over five hundred and thirty-eight thousand views. ${ }^{8}$

Both of these outlandish advertisements are permissible, although certainly not advisable, under the ABA Model Rules of Professional Conduct, which today require attorneys to avoid "false or misleading" communications regarding their legal services. ${ }^{9}$

The dental profession also has its fair share of professionals who have gone to extreme lengths to get the attention of consumers. In 2018, the Renaissance Dental Center in Raleigh, North Carolina, promoted its teeth-whitening treatments in a regrettable manner. ${ }^{10}$ Three Caucasian dentists from the practice were featured in the advertisement wearing "cultural garb," such as a Scottish highlander outfit, a Native American styled costume, and a Japanese kimono. ${ }^{11}$

3. See Robert F. Boden, Five Years After Bates: Lawyer Advertising in Legal and Ethical Perspective, 65 MARQ. L. ReV. 547, 549-50 (1982).

4. Bates v. State Bar of Ariz., 433 U.S. 350, 384 (1977).

5. Martha Neil, Brewery Sues DUI Law Firm, Says Look-Alike 'Sessions Law' Mark Confuses 'Session Lager' Customers, ABA Journal (July 14, 2014, 9:55 PM), http://www. abajournal.com/news/article/brewery_sues_law_firm_for_trademark_infringement/ [https://perma.cc/FQ2E-LNGJ].

6. $I d$.

7. Jacob Gershman, Singing Texas Attorneys Warn: 'Don't Eat Your Weed', WaLl St. J. (July 11, 2016, 4:20 PM), https://blogs.wsj.com/law/2016/07/11/singing-texas-attorneys-warndon't-eat-your-weed/ [https://perma.cc/6F8Z-5HVD].

8. Id.; see also Hutson \& Harris, Attorneys \& Counselors, Don't Eat Your Weed, YouTuBE (Sept. 12, 2015), https:/www.youtube.com/watch?v=nQZRA7wft1I\&feature=youtu.be [https:// perma.cc/X4QG-WGHM].

9. Model Rules of Prof'l Conduct R. 7.1 (2018).

10. Kathleen Joyce, North Carolina Dentists Apologize for Wearing Cultural Garb in 'Ignorant and Offensive' Ad, Fox News (May 12, 2018), https://www.foxnews.com/lifestyle/northcarolina-dentists-apologize-for-wearing-cultural-garb-in-ignorant-and-offensive-ad [https://perma.cc/Q9ZG-TFK4].

11. Id. 
The advertisement bore the caption: "Everyone smiles in the same language!"12 The advertisement unsurprisingly received a large amount of criticism. ${ }^{13}$ Despite being an offensive and inadvisable way to promote a dental practice, the advertisement was permissible under the ADA's Code of Professional Conduct, which prohibits "false or misleading" communications. ${ }^{14}$

Contrast the above examples of professional advertising with that of Dr. Richard A. Borgner, D.D.S., a Florida-licensed general dentist. ${ }^{15}$ Dr. Borgner's practice was focused on implant dentistry, a practice area of dentistry comprised of the placement, restoration, and maintenance of dental implants. ${ }^{16}$ Dr. Borger sought to inform consumers in St. Petersburg, Florida, of the focus of his practice and of the credentials he had earned from the American Academy of Implant Dentistry and the American Board of Oral Implantology/Implant Dentistry. ${ }^{17}$ However, Dr. Borger was prohibited from advertising his practice in this way, not because the message it communicated was false or misleading, but because he wanted to present himself as a "specialist" in a practice area not recognized by the ADA. ${ }^{18}$

Florida is not the anomaly. In most states, a licensed dentist whose practice consists entirely of placing and restoring dental implants cannot represent to patients that he or she is a specialist in implant dentistry simply because the ADA has not recognized implantology as a certified dental specialty. ${ }^{19}$ Not only is such an advertisement void of false or misleading information, it accurately represents the focus of the dentist's practice and serves to provide the general public with information that will make choosing a practitioner easier. ${ }^{20}$ Nonetheless, due to the continued use of restrictive ADA guidelines, dentists in certain practice areas are unable to exercise their First Amendment rights to free commercial speech. ${ }^{21}$

Recent litigation signaled the beginning of an industry-wide change in which the limitations on dentists' ability to advertise as "specialists" in non-ADA certified specialties are slowly being removed. ${ }^{22}$ This move toward free commercial speech and less restrictive principles is valuable for individual

12. Id.

13. Id.; see also ADA Principles of Ethics ANd Code of Prof'L Conduct $\S 5 . F(2005)$ [hereinafter ADA PRINCIPLES $\S 5 . F]$.

14. Joyce, supra note 10; ADA PRINCIPLES $\S$ 5.F, supra note 13.

15. Borgner v. Brooks, 284 F.3d 1204, 1207 (11th Cir. 2002).

16. Id.; see also Frequently Asked Questions, Am. ACAD. OF ImPlant Dentistry https://www.aaid-implant.org/faqs/ [https://perma.cc/N9EM-FA26] (last visited Mar. 13, 2020).

17. Borgner, 284 F.3d at 1204, 1207.

18. Id.

19. Riley H. Lunn, Bellwether States are Recognizing New Dental Specialties, 36 J. OF Craniomandibular \& Sleep Prac., 211-13 (Aug. 2018) [perma.cc/2TBP-7U3U].

20. American Academy of Implant Dentistry v. Parker, 860 F.3d 300, 310 (5th Cir. 2017).

21. Lunn, supra note 19.

22. Id. 
dentists and the consumers of dental services. ${ }^{23}$ If the trend toward increased unrestrictive advertising for general dentists continues, either through judicial decisions, corrective legislation, or preemptive action by the leaders in the dental field, consumers will be better informed. ${ }^{24}$

This Note outlines the significant progress already achieved in the fight for dentists' First Amendment rights and argues that legislation is needed to remove the remaining restrictive statutes that limit their ability to advertise as specialists. In order to do so, Section I begins by detailing the role played by the ADA and state dental boards across the country. Section II then provides a brief background of commercial speech case law, which sets the foundation for an analysis of the circuit split between the $11^{\text {th }}$ and $5^{\text {th }}$ Federal Circuits in Section III. The circuit split illustrates the opposing arguments utilized by state dental boards and dental specialists. Section IV concludes with an up to date assessment of advertising in the dental profession and an analysis of how unrestricted dental advertising will benefit both the profession and the consumers of its services.

\section{THE STRUCTURE OF THE AMERICAN DENTAL ASSOCIATION AND STATE DENTAL BOARDS AND THE ROLE THEY PLAY IN REGULATING DENTAL SPECIALTIES}

To set the scene for the First Amendment claims examined in this Note, it is first necessary to introduce the main characters in the dental profession and explain the authority that each possesses. Part A is dedicated to the ADA, the trade association, advocacy group, and political body that sets the standards for its member dentists and has long been at the forefront of the profession. The ADA is composed of numerous commissions and governing bodies. Part B then introduces state dental boards: state-specific entities tasked with overseeing licensure, sanctioning, and the enforcement of rules and regulations for dental professionals. While the ability to enact laws is reserved for state legislatures, both the ADA and state dental boards play significant roles in restricting specialty advertisement.

\section{A. The American Dental Association}

The ADA is the foremost authority on dental licensing and accreditation in the United States, advocating for dentists across the country since its creation in $1859 .{ }^{25}$ The trade association's mission is to "power the profession of dentistry and to assist our members in advancing the overall oral health of their patients." ${ }^{26}$

23. Id.

24. Michael W. Davis, Federal Court Decision on Dental Specialties - Interview with Frank R. Recker, DDS, JD, Dentist THE MENACE (Feb. 9, 2016), http://blog.dentistthemenace.com/2016/ 02/federal-court-decision-on-dental.html [https://perma.cc/A7EU-SF82].

25. See Presidents \& History of the ADA, Amer. Dental Assoc., https://www.ada.org/en/ about-the-ada/ada-history-and-presidents-of-the-ada [].

26. About the ADA, Am. Dental Ass'n, https://www.ada.org/en/about-the-ada (last visited Mar. 11, 2020) [https://perma.cc/7SMA-3346]. 
The ADA's membership consists of over 161,000 dentists, including both general dentists and practitioners who attended post-doctorate residencies such as Orthodontists and Oral Surgeons. ${ }^{27}$

Much like its legal counterpart (the ABA), the ADA sets the professional standards for dentistry. ${ }^{28}$ Its governance is comprised of a legislative body called the ADA House of Delegates ("the House") and a Board of Trustees. Established in 1913, the House is charged with the responsibility of determining the recognition of dental specialties, organizations, and certifying boards. ${ }^{29}$ The House is a political body, comprised of 483 members that are elected by fiftythree dental constituent societies. ${ }^{30}$

These governing bodies are defined as "policy recommending agencies," meaning that they publish guidelines and recommendations, but do not have the authority to enact laws. ${ }^{31}$ State legislatures working in conjunction with state dental boards, discussed in detail below, decide whether ADA recommendations are incorporated by reference, partially adopted, or ignored.

Despite the lack of law-making authority, the ADA wields immense power over the dental profession. ${ }^{32}$ The ADA supervises various commissions that oversee essential aspects of dentistry. ${ }^{33}$ The Commission on Dental Accreditation ("CODA") "develop[s] and implement[s] accreditation standards" for dental schools and post-dental school residency programs. ${ }^{34}$ Graduation from a CODAapproved school is in turn required for licensure by each state's dental board and graduation from a CODA-approved residency is required for membership in an ADA-recognized specialty. ${ }^{35}$ The ADA also oversees the Joint Commission on National Dental Examinations which is responsible for the development and administration of the national board examinations. ${ }^{36}$ Passage of board

27. $I d$.

28. Ronald. S Brown, Emerging Dental Specialties and Recognition, Dentistry Today (Mar. 1, 2018, 5:00 PM), http://www.dentistrytoday.com/viewpoint/10411-emerging-dentalspecialties-and-recognition [https://perma.cc/C7X9-W77L].

29. H.C. Simmons III, My Journey Through the Specialty Recognition Process with the American Dental Association, J. Tenn. Dent. Assoc. 5 (Spring 2004).

30. House of Delegates, AM. DENTAL Ass'N, https://www.ada.org/en/membercenter/leadership-governance/house-of-delegates [https://perma.cc/5AFY-F7ED] (last visited Mar. $11,2020)$.

31. Leadership and Governance, AM. DENTAL Ass'N, https://www.ada.org/en/membercenter/leadership-governance [https://perma.cc/8R4D-QQBC] (last visited Mar. 4, 2020).

32. Lunn, supra note 19.

33. Leadership and Governance, supra note 31.

34. CODA Mission, AM. Dental Ass'N, https://www.ada.org/en/coda [https://perma. cc/BN7L-LAU9] (last visited Mar. 4, 2020).

35. Id.

36. National Board Dental Examinations, AM. DentAL Ass'N, https://www.ada.org/en/ education-careers/national-board-dental-examinations [https://perma.cc/D35Y-L3Q5] (last visited Mar. 4, 2020). 
examinations is a requirement of licensure as well ${ }^{37}$ Finally, the Commission for Continuing Education Provider Recognition is a third ADA-run commission that regulates the standards and requirements of continuing education. ${ }^{38}$ State dental boards can adopt this commission's regulations and require dentists in their states to comply in order to maintain licensure. ${ }^{39}$ The ADA relies upon state dental boards for enforcement, but through its commissions, the ADA essentially dictates who enters the profession and the requirements to do so. ${ }^{40}$

While the ADA does not possess the power to enact rules and regulations, it maintains an evolving code of model principles and obligations that are generally adopted and enforced by state dental boards. ${ }^{41}$ All ADA member dentists "agree to abide by the Code as a condition of membership." 42 Titled "The ADA Principles of Ethics and Code of Conduct" ("the Code"), this Code provides guidance to dentists in all patient interactive aspects of their practices and provides a model of professional conduct. ${ }^{43}$ One such area is advertising. ${ }^{44}$ Section 5.F of the Code states, "although any dentist may advertise, no dentist shall advertise or solicit patients in any form of communication in a manner that is false or misleading in any material respect. ${ }^{\prime 45}$ In this respect, the ADA's stance on advertising is equivalent to the ABA's general provision on legal advertising as both trade associations enforce a "false or misleading" standard ${ }^{46}$

In a 1999 report by the ADA's Council on Ethics, Bylaws, and Judicial Affairs titled "Specialist Announcement of Credentials in Non-Specialty Interest Areas," the council expressed that the rationale for adopting this standard was based on the "protection of the public" since "[t]ruthful, nondeceptive advertising of a dentist's qualifications, services or facilities can help patients make informed choices about practitioners and services." ${ }^{\prime 7}$ The report further emphasized that "advertising which is false or misleading can harm patients by making it more difficult and costly for them to make informed choices." ${ }^{48}$

37. Id.

38. About the Commission for Continuing Education Provider Recognition, AM. DENTAL Ass'N, https://www.ada.org/en/ccepr/about-ccepr [https://perma.cc/F4FY-WS4P] (last visited Mar. 4, 2020).

39. Id.

40. Brown, supra note 28.

41. The ADA Principles of Ethics and Code of Conduct, Am. Dental Ass'n, https://www. ada.org/en/about-the-ada/principles-of-ethics-code-of-professional-conduct [https://perma.cc/SC7V-2UZD] (last visited Mar. 4, 2020).

42. The Council on Ethics, Bylaws and Judicial Affairs, Specialist Announcement of Credentials in Non-Specialty Interest Areas 3 (1999) [hereinafter The Council on ETHICS].

43. The ADA Principles of Ethics and Code of Conduct, supra note 41.

44. ADA Code $\S 5 . \mathrm{F}$, supra note 13.

45. Id.

46. Model Rules R. 7.1, supra note 9.

47. The Council on ETHICs, supra note 42.

48. Id. 
The motivation for this report can be found in the section titled "Ethical Concerns Raised by Advertising of Credentials by General Dentists.." 49 The report claims that advertisement of credentials is inherently problematic since there is "no standardized, nationally accepted program for recognizing achievement in non-specialty interest areas." ${ }^{.50}$ As a result, "[e]ducational qualifications for these credentials range from nonexistent to a basic weekend continuing education course to two years of formal, full- time education." ${ }^{51}$ It would unquestionably be improper if a dentist could declare expertise based solely on attending a one- or two-day class, but by adopting and enacting this rationale, the ADA placed such dentists in the same classification as those who underwent extensive and rigorous training to obtain credentials.

Through the ADA Code, the ADA exercises immense control on dental specialties and a dentist's ability to advertise as a specialist. ${ }^{52}$ The ADA historically limited its definition of dental specialties to those that have successfully applied to the House for recognition..$^{53}$ As of 2018, the nine recognized specialties are:

- Pediatric Dentistry,

- Periodontia,

- Prosthodontics,

- Oral Surgery,

- Oral Pathology,

- Orthodontics,

- Public Health,

- Endodontics, and

- Oral and Maxillofacial Radiology. ${ }^{54}$

Dentists in practice areas not recognized as specialties by the ADA, such as Implantology and Dental Anesthesiology, have been unable to advertise as specialists under the ADA's traditional regulations. ${ }^{55}$ The ADA incorporated this regulatory scheme "to help the public make an informed selection between the practitioner who has completed an accredited program beyond the dental degree and a practitioner who has not completed such a program. ${ }^{.56}$ More specifically, Section 5-H of the ADA Code outlined the following guidelines for limiting specialty advertisement:

49. Id.

50. Id.

51. Id.

52. Lunn, supra note 19.

53. Id.

54. Brown, supra note 28.

55. Lunn, supra note 19.

56. See generally ADA Principles of Ethics And Code of Prof'l Conduct § 5.H (2018) [hereinafter ADA CODE $\S 5 . \mathrm{H}]$. 
1. The special area(s) of dental practice and an appropriate certifying board must be approved by the American Dental Association.

2. Dentists who announce as specialists must have successfully completed an educational program accredited by the Commission on Dental Accreditation, two or more years in length, as specified by the Council on Dental Education, or be diplomates of an American Dental Association recognized certifying board. The scope of the individual specialist's practice shall be governed by the educational standards for the specialty in which the specialist is announcing.

3. The practice carried on by dentists who announce as specialists shall be limited exclusively to the special area(s) of dental practices announced by the dentist. ${ }^{57}$

Until recently, nearly all state dental boards adopted Section 5-H which effectively prevented dentists with credentials in specialties other than the nine recognized by the ADA from advertising those credentials. ${ }^{58}$

The ADA's decisions regarding specialty recognition were adopted by essentially all state boards in nearly every state, and the state legislatures implemented corresponding laws restricting the legality of specialty advertising. ${ }^{59}$ Since 1963, a single specialty, Oral and Maxillofacial Radiology, has successfully applied for recognition. ${ }^{60}$ Within this period, numerous practice areas represented by specialty-specific credentialing boards and membership associations have applied to the House for recognition but have been denied. ${ }^{61}$ This list includes:

- Implantology,

- Orofacial/Craniofacial Pain,

- Special Needs Dentistry,

- Oral Biology,

- Forensic Odontology,

- Geriatric Dentistry,

- Oral Medicine,

- Veterinary Dentistry, and

- Dental Anesthesiology. ${ }^{62}$

Four of these practice areas (Implantology, Dental Anesthesia, Orofacial Pain, and Oral Medicine) have unsuccessfully submitted multiple applications to the House. $^{63}$

57. Id.

58. Srinivasan Varadarajan, Is This The End Of General Dentistry As We Know It, AGD IMPACT, Nov. 2017, at 16.

59. Simmons, supra note 29 , at 5.

60. Id.

61. Lunn, supra note 19.

62. Id.

63. Susan E. Brackett, Update on Specialty Recognition, Am. Coll. of Prosthodontics, 
The political nature of the House is the source of much criticism from members of the specialties that have been denied recognition. ${ }^{64}$ After dental anesthesiology was denied recognition in 2012, Dr. Steven Ganzberg, president of the American Dental Board of Anesthesiology, stated, "We couldn't overcome the political nature of what the [House] is. This action by the ADA confirms that the ADA process of specialty approval is fatally flawed." ${ }^{65}$

Dr. Frank Recker echoed these sentiments, stating

[a]s dentists who have been members of the ADA for many years, when we think "specialty" we are conditioned to only think of the ADA. We don't consider the fact that the ADA is a political body and its "Specialty" decisions are ripe with considerations that should be excluded, such as competition, economic effects, and dental politics. ${ }^{66}$

Dr. Recker, an authority on dental specialty recognition and advertisement, began his career as a general dentist serving on the Ohio State Dental Board. ${ }^{67}$ Later, he transitioned into a legal career, focusing on dental issues, dental board defense, and the First Amendment Rights of dentists. ${ }^{68}$ Dr. Recker has gained immense recognition in the dental and legal communities for the success he has achieved while representing the plaintiff trade organizations and credentialing boards in many of the cases highlighted in this Note. ${ }^{69}$

The House's specialty recognition process was generally well-respected and unquestioned up through the 1970s in large part because advertisement was not allowed in any professional fields. ${ }^{70}$ Until recently, obtaining the status as an ADA-recognized specialty held insignificant value in terms of generating business because all dentists were prohibited from marketing their practices. ${ }^{71}$ This changed as the laws relating to commercial free speech evolved and dentists were allowed to use advertisement to their advantage. ${ }^{72}$ Through the $1980 \mathrm{~s}$ and $90 \mathrm{~s}$, the House repeatedly denied applications for specialty recognition on the

https://www.prosthodontics.org/about-acp/specialty-recognition-changes/ [https://perma.cc/RQQ9PPV2] (last visited Mar. 8, 2020).

64. Frank Recker, The Who, What, Why, and When of the American Board of Dental Specialties (ABDS), 43 J. OF ORAL IMPLANTOLOGY 85 (2017) https://meridian.allenpress.com/joi/ article/4\%20\%203/2/85/2551/The-Who-What-Why-and-When-\%20of-the-American-Board-of [perma.cc/XQ3X-ACFM].

65. Rob Goszkowski, Dental Anesthesiology Falls Short of Becoming ADA Specialty, DR.BICUSPID.COM (Nov. 1, 2012), https://www.drbicuspid.com/index.aspx?sec=log\&itemID= 311903 [https://perma.cc/KG7L-HJSP].

66. Davis, supra note 24.

67. Id.

68. Id.

69. Id.

70. Recker, supra note 64.

71. Id.

72. Simmons, supra note 29. 
grounds that the applications failed to meet the required criteria. ${ }^{73}$

Opposition to the House selection process is best exemplified by two controversial decisions. First, in 1999 the House announced Oral and Maxillofacial Radiology as the ninth recognized specialty. ${ }^{74}$ Three other specialties submitted applications for specialty recognition during the same application period, and yet only Radiology was given the ADA's approval. ${ }^{75}$ This decision came months after the United States Supreme Court's decision in California Dental Association v. Federal Trade Commission, in which the FTC explicitly confirmed that it possessed authority to eliminate restrictions placed by the California Dental Association that potentially had "a negative impact on market place competition." ${ }^{\text {" }}$ Since the advertising restrictions enforced by the California Dental Association were a direct byproduct of the ADA's recommendations, the ADA was alerted that the FTC would likely be turning its attention to the ADA in search of policies that resulted in restrictive trade. ${ }^{77}$ Dr. Recker, who at the time represented all four of the specialty applicants as legal counsel before the House, expressed his opinion that the ADA accepted Radiology's application in order to "diminish FTC scrutiny" and because Radiology was "deemed to be the least threat[ening] to the economic and marketplace competition among dentists." "78

Second, the American Dental Society of Anesthesiology ("ADSA") applied for the recognition of Dental Anesthesiology in 2012. ${ }^{79}$ This marked the fifth application of Dental Anesthesiology for specialty recognition. ${ }^{80}$ In this attempt, ADSA acquired the recommendations for approval from all fifty-three constituent councils, numerous committees, and the ADA board of trustees. ${ }^{81}$ Nonetheless, ADSA's application was denied in large part due to the efforts of the American Association of Oral and Maxillofacial Surgeons ("AAOMS"), who, according to Dr. Recker, "felt economically threatened by the creation of a dental specialty in anesthesia." 82 Depositions from a 2017 lawsuit against the Texas Board of Dentistry detailed how AAOMS "effectively lobbied, crusaded, and spread misinformation about the lack of any need for dental anesthesiologists, and how it might hamper the delivery of dental care." ${ }^{\prime 3}$ Dr. Recker represented the

73. Recker, supra note 64.

74. Id.

75. Id.

76. Recker, supra note 64 (discussing California Dental Ass'n v. F.T.C, 526 U.S. 759 (1999)).

77. Recker, supra note 64.

78. Id.

79. Daniel L. Orr II, The Development of Anesthesiology in Oral and Maxillofacial Surgery, 25 Oral Maxillofacial Surgery Clinic N. Am. 341, 353 (2013) https://www.asdahq.org/ sites/default/files/History.ofOMS_.Anesthesia.Orr_.pdf [https://perma.cc/M35D-YPXZ].

80. Id.

81. Recker, supra note 64.

82. Id.

83. Id. 
plaintiffs in this federal court challenge and commented that after witnessing the House's handling of ADSA's specialty application, it was clear to him that "the specialty game had been revealed in 2012 as a political process among economic competitors, and the self-evident nature of professional advertising and marketplace competition had overwhelmed any objectivity of the ADA specialty recognition process." ${ }^{\prime 4}$ The First Amendment claims that have been brought against state dental boards stemmed in large part from frustration with the ADA's handling of the specialty application process.

\section{B. State Dental Boards}

State dental boards are the second key player in regulating the dental profession and hold a crucial role in the resulting commercial speech lawsuits. ${ }^{85}$ Since the ADA is a professional trade association and not a legislative body, state dental boards carry the burden of enforcing the rules of the profession. ${ }^{86}$ The ADA's website defines a state dental board as "an agency of state government created by the state legislature" that "governs the qualifications for and the practice of dentistry within the state." protection of the public, while advocacy on behalf of dentists on the state level is left to state dental associations.

Each state dental board's authority is limited to the extent that their respective state legislature allows. ${ }^{88}$ The most common powers granted to state boards include the establishment of qualifications for licensure, issuance of licenses to qualified individuals, establishment of standards of practice and conduct, taking disciplinary action against those who engage in misconduct, and promulgation of rules to enable the board to perform its duties. ${ }^{89}$ For example, Indiana Code section 25-14-1 establishes the authority of the Indiana State Board of Dentistry, the parameters of membership on the Board, the Board's authority to regulate licensure, and the numerous other powers held by the Board. ${ }^{90}$ As is the general practice, the Indiana Board consists of the following: (1) "nine (9) practicing dentists licensed under IC 25-14 who must have been in practice in Indiana for not less than the five (5) years," (2) a "practicing dental hygienist," and (3) "one (1) member to represent the general public who must be a resident to this state and in no way associated with the profession of dentistry other than as a

84. Id.

85. See Borgner v. Brooks, 284 F.3d 1204, 1207 (11th Cir. 2002); Am. Acad. of Implant Dentistry v. Parker, 860 F.3d 300 (5th Cir. 2017).

86. Licensure Overview, AM. DENTAL Ass'N, https://www.ada.org/en/educationcareers/licensure [https://perma.cc/6DBR-YRJG] (last visited Mar. 9, 2020).

87. Id.

88. Id.

89. Id.

90. IND. CoDE $§ 25-14-1$ (2015). 
consumer." ${ }^{91}$

As a result of the legal structure of state dental boards in relation to the ADA, state dental boards are under no explicit requirement to adopt all aspects of the ADA Code or enforce adherence to it by the dentists in their state. However, the reality is that most state dental boards do adopt the guidance of the ADA. This is particularly true regarding the ADA's limitation of specialty advertising to only ADA-recognized specialties. Dr. H. Clinton Simmons III, a widely published dental scholar, researcher, and past president of the Tennessee Dental Association, ${ }^{92}$ held that "whether a state board recognizes a discipline of dentistry as a specialty almost always depends on whether the ADA recognizes that discipline as a specialty." ${ }^{93}$

The ADA has continually stressed to state dental boards that it is the boards' obligation to protect the interests of dental patients by prohibiting misleading promotions of dental practices. ${ }^{94}$ The ADA suggests that state dental boards uphold their obligation by "prohibit[ing] specialty advertising by general dentists with inadequate training and experience in the specialty that they purport to have." 95

\section{AN OVERVIEW OF COMMERCIAL SPEECH UNDER THE FIRST AMENDMENT}

Case law has defined commercial speech as "expression related solely to the economic interests of the speaker and its audience." ${ }^{.96}$ Prior to 1976, commercial speech was not protected to any degree by the First Amendment. ${ }^{97}$ In Virginia Pharmacy Board v. Virginia Citizens Consumer Council, the United States Supreme Court determined that the First Amendment protects commercial speech from unwarranted governmental regulation. ${ }^{98}$ The Court later asserted that "commercial expression not only serves the economic interest of the speaker, but also assists consumers and furthers the societal interest in the fullest possible dissemination of information." 999

Four years after Virginia Pharmacy Board, Central Hudson Gas \& Electric Corporation v. Public Service Commission increased the protection provided to

91. IND. CODE § 25-14-1-2 (2015).

92. House of Delegates, supra note 30.

93. Simmons, supra note 29.

94. Statement of the American Dental Association on Regulation by State Boards of Dentistry of Misleading Dental Specialty Claims, Am Dental Ass 'N (Aug. 10, 2018), https://www.aae.org/specialty/wp-content/uploads/sites/2/2018/09/bierigspecialtyadvpaper0818002.pdf [perma.cc/3FHC-QNQX].

95. Id.

96. Cent. Hudson Gas \& Elec. Corp. v. Public Serv. Comm'n, 447 U.S. 557, 561 (1980); Va. St. Bd. of Pharmacy v. Va. Citizens Consumer Council, 425 U.S. 748, 762 (1976).

97. Cent. Hudson Gas \& Elec. Corp., 447 U.S. at 584, see e.g. Breard v. Alexandria, 341 U.S. 622 (1951).

98. Va. St. Bd. of Pharmacy, 425 U.S. at 761-62.

99. Cent. Hudson Gas \& Elec. Corp., 447 U.S. at 561-62. 
commercial speech and has since become the hallmark case on the subject, providing an analysis to determine the constitutionality of statutes that limit commercial speech. ${ }^{100}$ Under the new regime established by Virginia Pharmacy Board, Central Hudson Gas \& Electric Corp. brought suit against the New York Public Service Commission ("Commission") claiming that the Commission's complete bar on "all advertising that [promotes] the use of electricity" was unconstitutional. ${ }^{101}$ The Commission established this restrictive policy during a period where the state of New York had insufficient fuel supplies and then elected to keep the ban in place after the shortage ended. ${ }^{102}$ The Commission reasoned that all "promotional" advertising of this nature was "contrary to the national policy of conserving energy." 103 An additional concern was that promotional advertising would give consumers "misleading signals." 104

The Supreme Court stated that consumers "will perceive their own best interest if only they are well enough informed, and ... the best means to that end is to open the channels of communication, rather than to close them." 105 The Court emphasized that "even when advertising communicates only an incomplete version of the relevant facts, the First Amendment presumes that some accurate information is better than no information at all."106

The holding in Central Hudson provides a four-part test, known as the four Central Hudson guideposts, that can be applied to commercial speech restrictions. ${ }^{107}$ The first Central Hudson guidepost states that First Amendment protection is given only to commercial speech that "accurately inform[s] the public about lawful activity." 108 The reasoning is that First Amendment protection of commercial speech has its foundation in the informational function of advertising. ${ }^{109}$ It follows that "the government may ban forms of communication more likely to deceive the public than inform it [as well as] commercial speech related to illegal activity." 110

The second guidepost of the Central Hudson analysis requires the State to "assert a substantial interest to be achieved by restrictions on commercial speech." 111 The Supreme Court has stated that regulations on commercial speech that "only indirectly advance the state interest" do not satisfy this requirement of

100. Borgner v. Brooks, 284 F.3d 1204, 1208 (11th Cir. 2002).

101. Cent. Hudson Gas \& Elec. Corp., 447 U.S. at 558.

102. Id. at 559.

103. Id.

104. Id. at 560 .

105. Va. St. Bd. of Pharmacy, 425 U.S. at 770.

106. Cent. Hudson Gas \& Elec. Corp., 447 U.S. at 562.

107. Id. at 566 .

108. Id. at 563 .

109. First Nat'l Bank of Bos. v. Bellotti, 435 U.S. 765, 783 (1978).

110. Cent. Hudson Gas \& Elec. Corp., 447 U.S. at 564.

111. Id. 
the Central Hudson analysis. ${ }^{112}$

The third prong of the commercial speech analysis is applied if the prior two portions were affirmatively answered, meaning that the speech in question presents a legal and accurate message and is regulated or restrained due to a substantial state interest. The next question the court must answer is "whether the regulation directly advances the governmental interest asserted." 113

The fourth and final part of the Central Hudson analysis requires determining whether the government's method of regulation is more extensive than necessary to serve their stated interest. ${ }^{114}$ The Court specified that "the regulatory technique must be in proportion to [the state's] interest," and "the limitation on expression must be designed carefully to achieve the State's goal.".15 In other words, restrictions on speech must be "narrowly drawn," 116 and information is unjustifiably suppressed when "narrower restrictions on [an] expression would serve [the state's] interest as well." 117 The Central Hudson analysis remains the gold standard of commercial speech protection and plays an important role in evaluating the First Amendment claims of dentists in non-ADA recognized specialties. The four Central Hudson guideposts are the backbone of the analysis in the Fifth and Eleventh Circuit cases detailed in Section III. Despite the vast similarities shared by the two cases, the circuits reached opposing conclusions while applying the same guideposts. ${ }^{18}$

\section{ANALYSIS OF THE FIFTH AND ELEVENTH CIRCUIT SPLIT}

Separated by just over a decade, two Federal Courts of Appeals reached conflicting decisions regarding challenges to state dental boards' limitations of dental specialty advertising. The circuit split between the Fifth and Eleventh Circuits demonstrates the stoutest arguments and policy concerns of both the state dental boards and the dental specialty accreditors that advocate for dentists across the country. Additionally, analysis of the Fifth and Eleventh Circuits' opinions provides a view of the alternative routes that dental specialist advertising will likely take going forward.

\section{A. Borgner v. Brooks - United States Court of Appeals for the Eleventh Circuit}

Borgner v. Brooks presents the appeal of the defendant Florida Board of Dentistry ("Florida Board") following a ruling in favor of the plaintiff, a Florida

112. Id.; see Va. St. Bd. of Pharmacy v. Va. Citizens Consumer Council, 425 U.S. 748, 769 (1976).

113. Id.

114. Id.

115. Id. at 564 .

116. In re Primus, 436 U.S. 412, 438 (1978).

117. Cent. Hudson Gas \& Elec. Corp., 447 U.S. at 565.

118. Borgner v. Brooks, 284 F.3d 1204, 1207 (11th Cir. 2002); Am. Acad. of Implant Dentistry v. Parker, 860 F.3d 300, 304 (2017). 
dental implant specialist, Dr. Richard A. Borgner, D.D.S. ${ }^{119}$ Borgner challenged the constitutionality of Florida Statutes $\S$ 466.0282, which "requires Floridalicensed dentists to include disclaimers when advertising specialty areas not recognized by the state and when advertising credentials from non-state approved credentialing organizations." 120 The rationale behind the statute is that Florida's legislature "wants the public to be informed that some dental specialties and some organizations recognizing these specialties are not sanctioned by the ADA and or the Florida Board." 121 More specifically, the statute attempts to avoid misleading the public "regarding the specialization and particular credentials of dentists." 122 Subsection (4) expressly states that in the mind of the Florida Legislature, regulation provided by $\S 466.0282$ is "the least restrictive means available to ensure consumers will not be misled." 12

Borgner advertised himself as a member of the American Academy of Implant Dentistry ("AAID"), a Fellow of the AAID, and a Diplomate of the AAID's certifying board, the American Board of Oral Implantology/Implant Dentistry ("ABOI/ID"). ${ }^{124}$ Implant dentistry is not one of the nine ADA recognized dental specialties and is also not recognized as a specialty by the Florida Board. ${ }^{125}$ Interestingly, this was not the first lawsuit brought by Borgner regarding $\S 466.0282$. Borgner previously claimed, and the court agreed, that the statute was unconstitutional in 1998, when the statute "prohibited Floridalicensed dentists from advertising a specialty practice." ${ }^{26}$ Following the 1998 suit, § 466.0282 was amended by the Florida Legislature to its current form requiring the disclosure. ${ }^{127}$

The Eleventh Circuit applied the Central Hudson analysis to Borgner's claim, first determining that "the statute's meaning is to be plain and unambiguous on its face" and "does not completely ban advertising of membership or credentials in the AAID and ABOI." ${ }^{28}$ In applying the first prong of the test, the Court determined that the advertising in question was only "potentially misleading" and therefore required application of the remaining three prongs. ${ }^{129}$ "Advertising that is only potentially misleading cannot be restricted unless the other three prongs of the Central Hudson test are met." 130

The statute in question satisfied the second prong because the Court believed

119. Borgner, 284 F.3d at 1207.

120. Id. See Fla. STAT. § 466.0282(1) (2018).

121. Borgner, 284 F.3d at 1209.

122. Id.

123. Id.

124. Id. at 1207.

125. Id.

126. Borgner v. Cook, 33 F. Supp. 2d 1327, 1333 (N.D. Fla. 1998).

127. Borgner, 284 F.3d at 1207.

128. Id. at 1208 .

129. Id. at 1210 .

130. Id. 
that the Florida Board had a substantial interest, and in fact was required to regulate the dental profession which is accomplished in part by establishing uniform standards of certification. ${ }^{131}$ States have a general interest in regulating professions and "have broad power to establish standards for licensing practitioners." 132 The state's interest "carries with it a responsibility to ensure that professional advertisements do not mislead consumers about which practitioners enjoy state approval and recognition." ${ }^{133}$ The Eleventh Circuit specifically defined the State of Florida's interest as "protecting its citizens from unqualified and incompetent health care professionals." 134 In order to achieve this interest, the Florida Board was required to ensure that "dental advertisements are not misleading to consumers with respect to those credentialing standards."

The Eleventh Circuit held that the statute satisfied the third prong and that the state was able to "demonstrate that the challenged regulation advances the Government's interest in a direct and material way." ${ }^{135}$ To satisfy this prong, a state must present tangible evidence that the restriction protects consumers from misleading and harmful commercial speech. ${ }^{136}$ Here, tangible evidence was in the form of two telephone surveys that demonstrated that the "restriction on Borgner's advertising directly addresses an actual harm." 137 The court concluded the surveys successfully showed that consumers would think that credentials such as the ones advertised by Borgner were recognized by Florida and the ADA. ${ }^{138}$

The court clarified that the source of harm is not that the AAID and similarly situated organizations were not bona fide credentialing organizations, but rather that "consumers will be led into thinking that implant dentistry and the AAID/ABOI meet state standards for recognition, when in fact, they do not."139 Testimony presented by the state's expert witness demonstrated that "consumers respondents rely heavily on the approval of the ADA in evaluating both general and specialized dentists." 140 The survey results evidenced that consumers find it difficult to distinguish between AAID and ADA certification. ${ }^{141}$

Lastly, § 466.0282 satisfied the fourth prong as the court held that the disclaimer requirements were not "especially long or burdensome, but simply an effective manner to convey necessary information to the public." ${ }^{142}$ The statute did not require dentists to set out the AAID's requirements for recognition. The court essentially ignored the obvious argument by the plaintiffs that the

131. Id. at 1212 .

132. Fla. Bar. v. Went for It, Inc., 515 U.S. 618, 625 (1995); Borgner, 284 F.3d at 1211.

133. Borgner, 284 F.3d at 1211.

134. Id.

135. Id.

136. Ibanez v. Fla. Dep't of Bus. \& Prof'1 Regulation, 512 U.S. 136, 147 (1994).

137. Borgner, 284 F.3d at 1211.

138. Id.

139. See id. at n.7.

140. Id. at 1213.

141. Id.

142. Id. at 1215. 
disclaimer requirements would undermine the "credibility" of their non-ADA approved credentials. ${ }^{143}$ The Eleventh Circuit concluded that Florida is justified in regulating commercial speech in this manner and that doing so allows consumers to make informed decisions when selecting a dental professional. ${ }^{144}$ As such, the Florida statute was deemed constitutional. ${ }^{145}$

\section{B. American Academy of Implant Dentistry v. Parker - United States Court of Appeals, Fifth Circuit}

Over a decade after the Eleventh Circuit upheld the Florida Board's regulation of commercial speech in Borgner, the Fifth Circuit reached an opposing decision in American Academy of Implant Dentistry v. Parker in 2017. This resulted from a lawsuit brought by dentists whose practice areas were not among the specialties recognized by the ADA and who claimed that Texas Administrative Code section 108.54 violated their First Amendment rights. ${ }^{146}$ The co-plaintiffs were three individual dentists, the AAID, the American Society of Dental Anesthesiologists, the American Academy of Oral Medicine, and the American Academy of Orofacial Pain. The organizational plaintiffs were all sponsors of credentialing boards. ${ }^{147}$ The lawsuit named the Texas State Board of Dental Examiners ("Texas Board") and each of its members as defendants. ${ }^{148}$

Texas Occupations Code section 254.002(b) gave the Texas Board the authority to "adopt and enforce reasonable restrictions to regulate advertising relating to the practice of dentistry." 149 The Texas Board adhered to Texas Administrative Code section 108.54 which limits dental advertising of specialties to practice areas that are recognized by a board that certifies specialists and is accredited by CODA. ${ }^{150}$ "The Board did not itself certify specialties but instead relies exclusively on the ADA for that purpose," a common practice among state dental boards. ${ }^{151}$

At the time of the lawsuit, Texas law provided two alternative routes by which dentists that were not qualified to advertise under section 108.54 could advertise their credentials and specialty practice offerings. Section 108.55 required such dentists to "include a disclaimer that they were general dentists and did not imply specialization." 152 Section 108.56 required that advertisements

143. Id. at 1219 (Hill, J., dissent).

144. Id. at 1216.

145. Id.

146. Am. Acad. of Implant Dentistry v. Parker, 860 F.3d 300, 304 (2017).

147. Id.

148. Id.

149. TEX. Occ. CODE $\S 254.002$ (b) (2018).

150. TeX. Admin. Code $\S 108.54($ a) (2018).

151. Am. Acad. of Implant Dentistry, 860 F.3d at 300, 305.

152. Tex. Admin. Code $\S 108.55$ (2018). 
"avoid any communications that express or imply specialization."153 The plaintiffs argued that these statutes prevented them from "truthfully holding themselves out as 'specialists' in their fields." 154

The Central Hudson analysis led the majority of the court to hold that the statutory restrictions unconstitutionally restricted the plaintiff's commercial speech. ${ }^{155}$ Addressing the first prong, the court stated that the statute unquestionably addressed lawful speech and held that the speech was only "potentially misleading" despite strong disagreement from the Texas Board that the term "specialist" is inherently misleading when presented in "the context of unregulated dental advertising" where it is "devoid of intrinsic meaning." 156 The court stated that the term "specialist" is not intrinsically devoid of meaning as it "conveys a degree of expertise or advanced ability." 157 The court highlighted that the Texas Board's "complete absence of evidence of deception" strengthened their opinion that the speech is only potentially misleading. ${ }^{158}$

The second prong was easily satisfied as both parties conceded that the Texas Board demonstrated substantial interests behind the restrictions, namely, "ensuring the accuracy of commercial information in the marketplace, establishing uniform standards for certification and protecting consumers from misleading professional advertisements." 159

The Fifth Circuit held that section 108.54 failed to satisfy the third prong of the analysis because the Texas Board "offer[ed] no justification for the line that it [drew] other than its unsupported assertion that the ADA 'should maintain the national gold standard." "160 The Texas Board failed its burden of providing more than "mere speculation or conjecture," and the court determined that the Texas Board's presentation of the two surveys that the Eleventh Circuit relied upon in Borger v. Brooks did not qualify as "empirical data." 161

The Fifth Circuit also held that the statute failed to satisfy the fourth Central Hudson prong and reasoned that "Section 108.54 completely prohibits the plaintiffs from advertising as specialists in their fields solely because the ADA has not recognized their practice areas as specialties" and found the fact that the Texas Board had not expressly considered less restrictive alternatives to be troublesome. ${ }^{162}$

153. $\S 108.56$.

154. Am. Acad. of Implant Dentistry, 860 F.3d at 300, 305 .

155. Id. at 306 .

156. Id. at 307.

157. Id.

158. $I d$. at 308 .

159. Id. at 309 .

160. Id. at 310 .

161. Id. at 309-10. Interestingly, the Fifth Circuit distinguished the disclaimers in Florida Statutes section 466.0282 and Texas Administrative Code section 108.54 despite that fact that both statutes provide the same essential effect - they allow a dentist to advertise their specialty under the condition that they clarify that it is not recognized by the ADA or state board.

162. Id. at 311 . 
The dissenting opinion in Parker found section 108.54 constitutional when analyzed under the Central Hudson test because the restricted speech is "inherently misleading" and fails the first prong. ${ }^{163}$ In the opinion of the dissenting judge, the state of Texas gave the term "specialist" a particular meaning in $\S 108.54$, and as a result the advertisements in question were inherently misleading when viewed in context of the statute. ${ }^{164}$

Comparison of the two Court of Appeals cases reveals two contrasting perspectives of very similar legal positions. Florida Statutes section 466.0282 and Texas Administrative Code section 108.54 apply the same requirements of disclosures and disclaimers for dentists that advertise a non-ADA recognized specialty, and yet the Central Hudson analysis of the Eleventh and Fifth Circuits reached polar opposite conclusions.

\section{THE ADA'S RESPONSE TO LITIGATION AND PREDICTIONS FOR THE FUTURE}

The final section of this note addresses the ADA's response to the numerous losses suffered by state dental boards and how this response will play out in the states that have yet to revise their own dental advertising laws. Part A gives a detailed breakdown of ADA House Resolutions 30 and 65 and the objectives that the ADA claims they will accomplish. Part B puts forth examples of states that have already undertaken some form of action to address the need for change to dental specialty advertising rules. These states serve as models for other states when they determine whether to make preemptive changes or stay the course, risking potential lawsuits against their state dental boards. Part B then proposes solutions for states that have yet to act on this matter. This is supported by claims that less restricted advertising is in the best interest of the consumer.

\section{A. The ADA's Response-ADA House of Delegates Resolution 30 and Resolution 65}

The ADA took drastic steps to alter the landscape of dental advertising and specialty recognition after dental boards that followed the ADA's recommendations suffered costly losses in three major states. ${ }^{165}$ First, a Florida state circuit court held Florida Statutes section 466.0282 (the same statute challenged in Borgner v. Brooks) unconstitutional because it suppressed dentists' "right to advertise legitimate credentials" thereby depriving them "of the benefits of their industry." 166 Importantly, the court's decision rested on the disclaimer required by the Florida statute. It stated that "[a]n advertisement containing the required disclaimer is tantamount to no advertising at all." ${ }^{67}$ The court did not declare the statute unconstitutional on the basis that it prevented the dentists from

163. Id. at 313 .

164. Id. at 314 .

165. Lunn, supra note 19.

166. Ducoin v. Viamonte Ros, 2009 WL 5574534. No. 2003 CA 696 (Fla. Cir. Ct. 2009).

167. Id. 
advertising as specialists, but rather because it prevented them from listing credentials earned from the AAID without including a disclaimer. ${ }^{168}$

One year later, the AAID won a suit in the United States District Court for the Eastern District of California. ${ }^{169}$ The court held unconstitutional a California statute that prevented dentists from advertising credentials issued by the AAID and other "bona fide, well-respected organizations," despite the fact that the credentials demonstrated proficiency in implant dentistry. ${ }^{170}$ The court noted that " $[t]$ he only evidence that the Dental Board offers that the advertising . . . would be misleading is conclusory, anecdotal, and speculative." 171 Judge John Mendez noted that the consumer is benefited from receiving information about the credentials a dentist has earned and stated, "Where is the harm in giving consumers more information about the ABOI/ID and the AAID credentialing programs? And the answer is there is no harm. It only benefits the consumer." 172

The third blow landed on the Texas State Board of Dental Examiners in 2017 as discussed in Section III. ${ }^{173}$ The dental boards of Florida, California, and Texas each incurred costs of over a million dollars after damages and attorney fees. ${ }^{174}$ The ADA received the message from the courts loud and clear. ${ }^{175}$ By the time the Borgner court had declared the Texas statute unconstitutional, the ADA had passed ADA HOD Resolution 65, which amended Section 5.H of the Code in two major ways. ${ }^{176}$

First, Section 5.H was amended to state that a dentist may now announce to the public that they are a specialist in any of the nine ADA recognized specialties as well as the following:

any other areas of dentistry for which specialty recognition has been granted under the standards required or recognized in the practitioner's jurisdiction, provided the dentist meets the educational requirements required for recognition as a specialist adopted by the American Dental Association or accepted in the jurisdiction in which they practice. ${ }^{177}$

Essentially, the ADA gave states the green light to exercise discretion in the question of expanding specialty recognition. ${ }^{178}$ The revised version of Section $5 . \mathrm{H}$ allows a state to determine which practice areas and credentialing bodies are

168. Id.

169. Bingham v. Hamilton, 100 F. Supp. 2d 1233 (E.D. California 2010).

170. Lunn, supra note 19.

171. Bingham, 100 F. Supp.2d at 1233, 1240.

172. AAID Credentials Ruled Bona Fide by U.S. District Court, Am. ACAD. Of ImPlant DENTISTRY (Nov. 16, 2010), https://www.prnewswire.com/news-releases/aaid-credentials-ruledbona-fide-by-us-district-court-108399454.html [https://perma.cc/9GUD-P4MY].

173. Am. Acad. of Implant Dentistry v. Parker, 860 F.3d 300, 314 (2017).

174. Lunn, supra note 19.

175. Brackett, supra note 63.

176. Varadarajan, supra note 58.

177. ADA CODE $\S 5 . \mathrm{H}$, supra note 56 .

178. Varadarajan, supra note 58; ADA Code $\S 5 . \mathrm{H}$, supra note 56. 
"bona fide," or in other words require a general dentist to demonstrate a level of sufficient expertise before they are credentialed, and then allow members of these chosen specialties to advertise as such. ${ }^{179}$

Second, Resolution 65 further amended Section 5.H to allow a dentist who announces himself or herself as a specialist to practice in all facets of dentistry, unless a specialist announces that his or her practice is "limited to" his or her specialty. ${ }^{180}$ As a result, a general dentist who was credentialed by the AAID could announce himself or herself as a specialist in implant dentistry without eliminating general dentistry cases from their practice. ${ }^{181}$ Dr. Frank Recker took a skeptical yet realistic view on the changes brought about by Resolution 65, stating that the move was "of little surprise" and done to prevent future lawsuits on the basis of restraint of trade. ${ }^{182}$

On October 27, 2018, the ADA altered the landscape of dental specialties even further. The House passed ADA HOD Resolution 30 and established the National Commission on Recognition of Dental Specialties and Certifying Boards ("Commission") with the mission of "provid[ing] an objective evaluation of dental specialties and their certifying boards." ${ }^{83}$ While not entirely independent from the ADA (the ADA provides half of the Commission's funding with the other half provided by the specialties ${ }^{184}$ ), the Commission effectively removes the ADA from the position of final determinant of the specialty recognition process. ${ }^{185}$ This decision was "intended to protect the specialty recognition process from any real or perceived influence by the ADA."186 The Commission is comprised of "nine general dentists, appointed by the ADA Board of Trustees, and a dentist from each of the nine recognized specialties, appointed by the sponsoring organization." 187

Time will tell how large the effect these two resolutions will have on the dental profession, but the AAID and advocates of other dental specialties seeking recognition unquestionably view the ADA's response as validation and large step in the right direction. The mounting lawsuits and belief that the ADA's specialty recognition process was no more than a "political process among economic

179. Varadarajan, supra note 58.

180. ADA CODE $\S 5 . \mathrm{H}$, supra note 56.

181. Varadarajan, supra note 58.

182. Recker, supra note 64.

183. Frank J. Tuminelli, Overview of the National Commission on Recognition of Dental Specialties and Certifying Boards, Am. Coll. of Prosthodontists (2018), https://www. prosthodontics.org/about-acp/specialty-recognition-commission-overview/ [https://perma.cc/SF9UDBYD].

184. Id.

185. Id.

186. Brackett, supra note 63.

187. Kimber Solana, ADA Appoints Members to Dental Specialty Commission, ADANews (Jan. 22, 2018), https://www.ada.org/en/publications/ada-news/2018-archive/january/ada-appointsmembers-to-dental-specialty-commission [https://perma.cc/T9DP-9VZR]. 
competitors" forced the ADA's hand. ${ }^{188}$ A report released by the American College of Prosthodontists shortly after the formation of the Commission stated that "[r]emoving the HOD's role in identifying a 'specialty' [was] critical in blocking the onslaught of court cases against the different states that defer to the 'ADA-recognized' specialties." 189 Dr. Frank Recker agreed, stating that the Commission's creation was "clearly intended to avoid the obvious self-interest complications of the HOD and to create the appearance of nonpolitical determinations of new specialties." 190

On March 11, 2019, the Commission proved that it was not merely an entity by which the ADA could insulate itself from liability. ${ }^{191}$ The Commission recognized Dental Anesthesiology as the tenth ADA recognized specialty, the first in twenty years and only the second since $1963 .{ }^{192}$ James Tom, DDS, MS, president of the American Society of Dentist Anesthesiologists ("ASDA"), stated that "[h]aving the ADA recognize the specialty of dental anesthesiology validates to us that the larger community of dental professionals is ready to . . . practice to a higher standard, and be committed to treat patients that otherwise could not be treated in traditional dental practice." ${ }^{, 193}$ Dr. Tom highlighted the role played by lawsuits ASDA filed against state boards, asserting, "Legal action at state dental boards certainly drove awareness of dental anesthesiology and legitimate and extensive pathways of specialized training to the forefront of regulators in the profession." dentistry would still remain the same as it has ever been without any meaningful change and self-reflection as to its obligation to treat patients from a wide variety of healthcare needs." 195

The recognition of Dental Anesthesiology weakens the attacks thrown at the ADA by its critics. Within six months of its formation, the Commission has boldly stated that it is willing to open up specialty recognition and that is not merely here to maintain the status quo of the past twenty years. On its face, this is great news for the trade associations and advocacy groups that have been involved in this fight for decades, but it is too early to determine whether the Commission will serve as the sole solution to the specialty advertisement problem. The recognition of an additional specialty may provide momentary hope and keep the lawsuits at bay for the time being, but the yet-to-be recognized

188. Recker, supra note 64.

189. Brackett, supra note 63.

190. Recker, supra note 64.

191. Michael W. Davis, ADA Now Recognizes Dental Anesthesiology as a Specialty, Dentistry Today (Mar. 12, 2019) https://www.dentistrytoday.com/news/todays-dental-news/item/4521-adanow - recognizes-dental-anest hesiology-as-a-s pecialty? fbclid=Iw AR0 ToopCvWsnws6shVe6kxy5zPMU6J571-_gh6ywoYY_SAl90nfBbtOz4w [https://perma.cc/MU5MWZXJ].

192. Id.

193. Id.

194. Id.

195. Id. 
practice areas will not remain quiet for long if the Commission takes no further action.

\section{B. Prediction of the States Reaction to the ADA's Recent Amendments}

Resolution 65 was a clear message from the ADA to state legislatures and dental boards that the time to address the specialty recognition issue is present. By significantly increasing state dental boards' ability to determine which specialties are recognized in their state, Resolution 65 will force each state to consider its appetite for litigation. Credentialing bodies such as the AAID have put forth an impressive track record in courtrooms across numerous jurisdictions. It logically follows that most states would preemptively enact the changes provided by the ADA, especially since the vast majority of states trusted the ADA's leadership by incorporating its previous stance.

In the short period following the ADA's new resolutions, a handful of states have taken steps to address specialty recognition and avoid litigation. In March 2018, the Ohio State Dental Board temporarily suspended specialty rulings. ${ }^{196}$ In a statement following the decision, the board explained that

not any dentist may claim to be specialist and advertise as such. The only dentist that may advertise as specialists are diplomates of a national certifying board of a specialty recognized by the American Dental Association or a diplomate of a certifying board currently recognized by the American Board of Dental Specialties (ABDS) until the Board revises said rules and the revisions become effective. ${ }^{197}$

The inclusion of ABDS-recognized specialties in the ruling and the implication that additional expansions are likely are evidence that the Ohio State Dental Board recognized the need to reevaluate specialty recognition before it is too late. Indiana, Iowa, and Massachusetts have undertaken similar amendments to their respective dental statutes, allowing specialty proclamations by ABDS recognized specialties. ${ }^{198}$

The North Carolina Board of Dental Examiners announced proposals to loosen the state's regulations pertaining to advertising as a specialist. ${ }^{199}$ The proposals sought to allow not only dentists in specialties recognized by the ADA to advertise as specialists, but also those approved by the ABDS and the Royal College of Dentists of Canada. ${ }^{200}$ The proposal brought opposition from groups

196. Lunn, supra note 19.

197. Id.

198. Id., see also 234 Mass. Code Regs. 5.03 (2019).

199. Lunn, supra note 19.

200. American Association of Orthodontists, North Carolina Dental Board Adopts AAO-Proposed Policy Wording for Specialty Advertising, AM. Ass ' $\mathrm{N}$ OF ORTHODOnTISTs (Feb. 8, 2019), https://www.aaoinfo.org/news/2019/02/north-carolina-dental-board-adopts-aao-proposedpolicy-wording-specialty-advertising [https://perma.cc/S2WY-TNP4]. 
such as the American Association of Orthodontists who claimed that "patients would best be served by not diluting the 'specialty' definition as proposed by the Board."201

Nonetheless, on January 17, 2019, the North Carolina Board adopted the proposed revisions to $21 \mathrm{NCAC} 16 \mathrm{p} .0105$, allowing a dentist to announce as a specialist in a practice area provided the dentist "has completed a qualifying postdoctoral educational program in that area," or "holds current certification by a qualifying specialty board or organization." 202 The regulation listed numerous criteria by which to identify a specialty board or organization as qualifying, such as hours of training, written and oral examination requirements, and provisions for periodic recertification. ${ }^{203}$ The law clearly intends to limit specialty classification to only those dentists who have put forth the commitment and effort to achieve a level of expertise in a practice area, and no doubt this effort would be applauded by plaintiffs such as the AAID who have long fought for recognition of such. ${ }^{204}$ Their argument has never been to allow a dentist with little experience or specialized training to proclaim him or herself a specialist merely because they attended a weekend seminar on a new implant placing technique. Rather, the dentists seeking to hold themselves out as specialists have expended considerable effort for the right to inform consumers of their bona fide credentials as the First Amendment affords them the right to do. ${ }^{205}$

Aside from the preemptive efforts listed above, few states have yet to react to the ADA's change in policy. A lawsuit between the AAID and the Indiana State Board of Dentistry was announced in late 2017, meaning Indiana could join Florida, California, and Texas as states that have been forced to amend their dental advertising statutes by way of judicial order. ${ }^{206}$

New Jersey declined to expand the scope of its specialty advertisement statute. In March 2017, Dr. Frank Recker petitioned the New Jersey State Board of Dentistry on behalf of the ABDS to amend the New Jersey statute. ${ }^{207}$ The petition requested that the amended statute "formally recognize the ABDSrecognized certifying boards [and] areas of practice as specialties" which would allow "diplomates of ABDS-certifying boards to advertise as specialists." ${ }^{\text {"208 }}$ After deliberation, on March 4, 2019, the statute was reenacted and limited specialty advertisement to (1) a licensed dentist who is certified or eligible for certification by a specialty board recognized by the American Dental Association, or (2) a licensed dentist who successfully completes a post-doctoral education of two or more years in duration in a program accredited by the American Dental

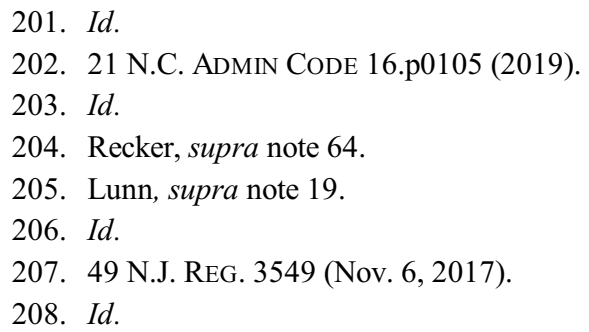


Association Council on Dental Education. ${ }^{209}$ By electing to give permission solely to the ADA, the New Jersey dental board could be a target of future litigation.

\section{CONCLUSION}

Dental specialty recognition needs to be addressed state by state. The preferable method is state legislation that adopts some version of the ADA's amended Code Section 5.H. Preferably, this would include express recognition of specialties approved by the ADA and the ABDS, and language that allows a state dental board to review an application from other credentialing entities and determine whether the application meets the requisite standard of quality. Action by the legislature is preferable for the following reasons:

First, it removes the need for long, costly litigation. State dental boards are fighting a losing battle in this regard. Additionally, in states where courts have declared specialty advertising statutes unconstitutional, any and all advertising of specialties is allowed. For example, any dentist in Florida, California, and Texas is able to advertise a specialty regardless of their credentialing. This is not preferable and is not what advocates of unrestricted specialty advertisement have fought for. Until the legislatures of these states pass a new statute, consumers could fall prey to misleading advertisement. For this reason, preemptive amendment by state legislatures before a statute is declared unconstitutional is the superior option.

Second, amendment of dental advertising statutes would place discretion and decision-making ability in the hands of the state dental board, the government agency comprised of practicing dentists that exists to protect the public. State boards can and should still prohibit specialty advertising by dentists with inadequate training and experience, and any other form of advertisement that is false or misleading. The public's best interest is served when the state boards "make substantive determination[s] of whether [ ] dental organizations are actually bona fide." But, no longer can state boards simply defer to the nine ADA recognized specialties and limit the First Amendment rights of other credentialed dentists. The ADA underwent reform and distanced itself from the specialty recognition process in the name of transparency, the promotion of unbiased market competition, and informing consumers. It is now up to the states to take advantage by adopting legislation allowing advertisement of any specialty recognized by the ADA, the ABDS, and all other credentialing entities that prove to be bona fide.

209. N.J. Admin CodE § 13:30-6.1 (2019). 